\title{
Pure oestrogen antagonists for the treatment of advanced breast cancer
}

\author{
Anthony Howell \\ CRUK Department of Medical Oncology, University of Manchester, Christie Hospital NHS Trust, Manchester M20 4BX, UK \\ (Requests for offprints should be addressed to A Howell; Email: maria.parker@ christie-tr.nwest.nhs.uk)
}

\begin{abstract}
For more than 30 years, tamoxifen has been the drug of choice in treating patients with oestrogen receptor (ER)-positive breast tumours. However, research has endeavoured to develop agents that match and improve the clinical efficacy of tamoxifen, but lack its partial agonist effects. The first 'pure' oestrogen antagonist was developed in 1987; from this, an even more potent derivative was developed for clinical use, known as fulvestrant (ICl 182,780, 'Faslodex'). Mechanistic studies have shown that fulvestrant possesses high ER-binding affinity and has multiple effects on ER signalling: it blocks dimerisation and nuclear localisation of the ER, reduces cellular levels of ER and blocks ER-mediated gene transcription. Unlike anti-oestrogens chemically related to tamoxifen, fulvestrant also helps circumvent resistance to tamoxifen. There are extensive data to support the lack of partial agonist effects of fulvestrant and, importantly, its lack of cross-resistance with tamoxifen. In phase III studies in patients with locally advanced or metastatic breast cancer, fulvestrant was at least as effective as anastrozole in patients with tamoxifen-resistant tumours, was effective in the first-line setting and was also well tolerated. These data are supported by experience from the compassionate use of fulvestrant in more heavily pretreated patients. Further studies are now underway to determine the best strategy for sequencing oestrogen endocrine therapies and to optimise dosing regimens of fulvestrant. At present, and for the foreseeable future, fulvestrant is the only oestrogen antagonist with no agonistic effects licensed for the treatment of advanced breast cancer in postmenopausal women. Other similar oestrogen antagonists are undergoing research and development, with a few currently being evaluated in phase II trials.
\end{abstract}

Endocrine-Related Cancer (2006) 13 689-706

\section{Background}

The critical role played by oestrogen in breast cancer has driven a huge amount of research into the development of hormonal therapies that are able to block oestrogen-mediated cell signalling. For more than 30 years, tamoxifen, a non-steroidal triphenylethylene derivative (Fig. 1), has been the drug of choice in treating patients with oestrogen receptor (ER)-positive and/or progesterone receptor (PgR)positive tumours. Not only is tamoxifen effective in patients with breast cancer, it also reduces the incidence of disease in healthy women at high risk of developing breast cancer (Cuzick et al. 2003). The success of tamoxifen has been achieved despite its partial agonist activity, which is associated with increased risk of endometrial cancer, thromboembolic events and tumour flare, particularly with long-term use. As such, research has endeavoured to develop agents that are at least as effective as tamoxifen but which lack its partial agonist effects.

First-generation selective ER modulators (SERMs, e.g. toremifene, droloxifene and idoxifene) were based on the non-steroidal triphenylethylene structure of tamoxifen (Wakeling 2000). These agents have no efficacy benefits over tamoxifen and also show partial agonist activity (Pyrhonen et al. 1994, Lee et al. 2000, Buzdar et al. 2002), with some studies suggesting there is cross-resistance 'between' first-generation SERMs and tamoxifen (Haarstad et al. 1992, Stenbygaard et al. 1993, Pyrhonen et al. 1994, 1997, 1999, Hayes et al. 1995, Gershanovich et al. 1997, Lee et al. 2000, Johnston et al. 2001, MillaSantos et al. 2001). Disappointing efficacy data for both droloxifene and idoxifene when compared with tamoxifen or when 


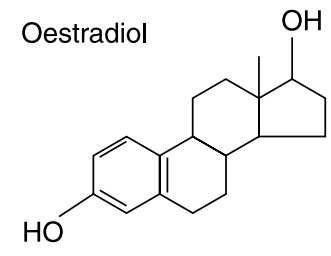

Tamoxifen

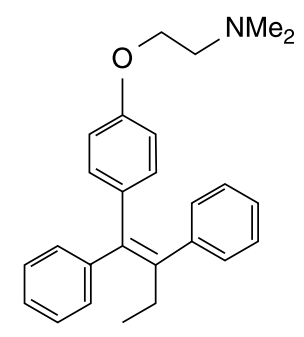

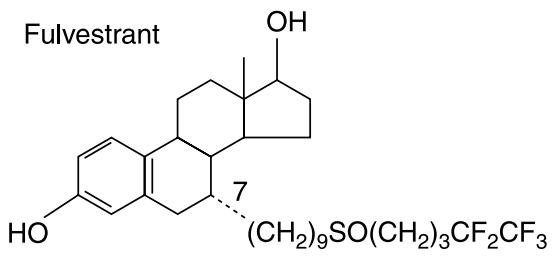

Raloxifene

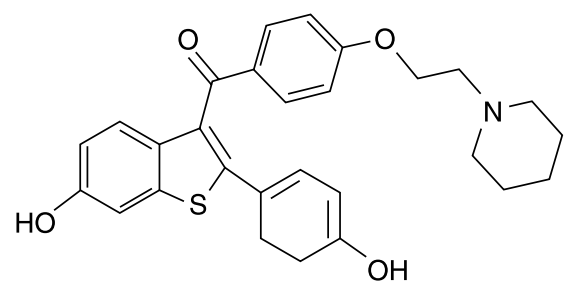

Figure 1 Chemical structures of oestradiol, tamoxifen, fulvestrant and raloxifene.

used in tamoxifen-resistant disease have led to their development being halted. Toremifene (chloro-tamoxifen), which has similar efficacy but fewer agonist properties compared with tamoxifen (Marttunen et al. 1998, 2001), remains in clinical development in the breast cancer prevention setting.

Structurally distinct second- and third-generation SERMs ('fixed-ring' benzothiophene derivatives (Fig. 1)) such as raloxifene, arzoxifene and ERA923 were then developed. Most of these have demonstrated anti-tumour activity in breast cancer but also have some partial agonist activity (Buzdar et al. 1988, Gradishar et al. 2000, Munster et al. 2001, Buzdar et al. 2003). Results from the Study of Tamoxifen and Raloxifene (STAR) trial, one of the largest breast cancer prevention studies, which has recruited 19000 postmenopausal women at risk of breast cancer, are expected in 2006. Based on its partial oestrogen agonist effects (Delmas et al. 1997), raloxifene is also currently being used for the prevention and treatment of osteoporosis and breast cancer. Arzoxifene showed promising initial results in a phase II study in advanced breast cancer, although its efficacy was greater in tamoxifen-sensitive than tamoxifen-resistant disease (Buzdar et al. 2003). Results from a phase I study suggest that ERA-923 has no trophic effects on the uterus (Cotreau et al. 2002), and its role in patients with breast cancer is currently being investigated.

The search for novel agents that would completely block all ER signalling led to the synthesis of a series of steroidal $7 \alpha$-alkylamide analogues of oestradiol. Of these, ICI 164,384 was the first pure oestrogen antagonist to be described, completely blocking the uterotrophic action of both oestradiol and tamoxifen in rats (Wakeling \& Bowler 1987). Following this, a far more potent pure oestrogen antagonist was developed, ICI 182,780, which is now known as fulvestrant ('Faslodex') (Fig. 1) (Wakeling et al. 1991). At present (and for the foreseeable future), fulvestrant, an oestrogen antagonist with no agonist effects, is licensed for the treatment of advanced breast cancer in postmenopausal women. Therefore, this paper will describe in detail the mode of action of fulvestrant, and explore how this underlies its clinical efficacy, tolerability and safety profile in the treatment of advanced breast cancer. In considering the future directions for oestrogen-antagonistic agents, ongoing clinical trials with fulvestrant will be reviewed. The current status of other 'pure' oestrogen antagonists in preclinical and clinical development will also be described.

\section{Mode of action}

\section{ER-mediated signalling}

The biological actions of oestrogen are mediated by two subtypes of ER, ER $\alpha$ and ER $\beta$. Both receptors belong to a family of ligand-activated nuclear transcription factors (Evans 1988) and share a high degree of homology in their DNA binding domains 
(Kuiper et al. 1996). However, they differ considerably in their N-terminal regions, which contain the ligandindependent transcription activation function, AF1 (Kuiper et al. 1996). These differences suggest that $\mathrm{ER} \alpha$ and $\mathrm{ER} \beta$ could have distinct functions in terms of gene regulation and may contribute to the selective action of oestradiol in different target tissues (Gustafsson \& Warner 2000). There is evidence from in vitro studies to suggest that imbalanced $\mathrm{ER} \alpha / \mathrm{ER} \beta$ expression may be a feature of oestrogen-dependent tumour progression and that ER $\beta$ has a key role in providing protection against $E R \alpha$-induced hyperproliferation (Bardin et al. 2004). It has also been suggested that ER $\beta$ may be a dominant regulator of oestrogen signalling as it causes a dose-dependent reduction in ER $\alpha$-mediated transcription when coexpressed with ER $\alpha$ (Lindberg et al. 2003).

\section{Classical pathway of ER signalling}

In classical ER signalling, unbound ER can be nuclear localised and bound loosely to the oestrogen response elements (ERE) (Kumar \& Chambon 1988, Reese \& Katzenellenbogen 1991). However, binding of oestradiol to the ER initiates a cascade of events leading to strong ER dimerisation, increased nuclear localisation and binding to ERE in the regulatory regions of target genes, and gene transcription (mediated by AF1 and AF2 of the ER) (Beato 1989, Tsai \& O'Malley 1994, Cheskis et al. 1997). AF1 (located in domains A and B of the amino terminal of the ER) is activated by growth factors acting through the mitogen-activated protein kinase (MAPK) pathway, while AF2 (located in domain $\mathrm{E}$ of the carboxy terminal of the ER ligandbinding domain) is activated by oestradiol. In the transcription complex, the activated AFs recruit coactivators and corepressors of oestrogen-regulated transcription (Horwitz et al. 1996, White \& Parker 1998), with full transcriptional activity requiring both AFs to be active. Ligand-specific conformational changes in the ER strongly influence the protein:protein interactions in the transcriptional complex, leading to differences in gene transcription and activation for ER-binding ligands (Brzozowski et al. 1997, Shiau et al. 1998). Indeed, ligand-dependent conformational changes in the ER show that there are distinct differences between oestradiol-ER, tamoxifen-ER and fulvestrant-ER complexes (Paige et al. 1999).

\section{Nonclassical pathways of ER signalling}

In addition to binding to classical ERE motifs, ERs can stimulate gene transcription via a nonclassical pathway by interacting with other transcription factors bound to promoters of responsive genes. Genes that are regulated by oestrogen but do not have an ERE include cyclin D1, p21 and the PgR (Shupnik 2004). Many such genes are regulated via ER interactions with stimulating protein 1 ( $\mathrm{Sp} 1)$, the signal transducers and activators of transcription (STAT) family of transcription factors and transcription factors associated with activating protein 1 (AP1) sites. The AP1 transcription factors are a family of homo- and heterodimers composed of proteins that belong to the Jun, Fos, Maf and ATF subfamilies that bind to 12-0-tetradecanoylphorbol-13-acetate (TPA) response elements (TRE) or cAMP response elements (CRE) in target genes (Chinenov \& Kerppola 2001). The c-Jun homodimer is the most potent transcriptional activator in the AP1 family (Matthews et al. 2006).

While both ER $\alpha$ and ER $\beta$ can bind oestradiol and activate transcription through an ERE, they have differential transcriptional activities at Sp1 and AP1 sites. Only $\mathrm{ER} \alpha$ can stimulate genes via the Sp1 pathway and the two isoforms are differentially regulated by oestrogens and antioestrogens at AP1 sites (Shupnik 2004). Results of a recent in vitro study suggested that ER $\beta$ may preferentially antagonise the nonclassical AP1-mediated pathway regulated by ER $\alpha$ (Matthews et al. 2006). Interestingly, another in vitro study suggests that ER expression may positively contribute to breast cancer growth in two ways. In normal situations, ER is activated by oestrogen to promote breast cancer cell proliferation, primarily through ERE-mediated transcription. However, in stressful conditions, such as during chemotherapy treatment, ER may facilitate breast cancer growth by inhibiting cell death via binding c-Jun and regulating AP1-mediated transcription (Qi et al. 2004).

\section{Ligand-independent ER signalling pathways}

During recent years, it has been documented that crosstalk between oestrogen and growth factor-stimulated intracellular signalling pathways can directly activate the ER and the transcription of ER-regulated genes in the absence of oestrogen (Weigel \& Zhang 1998). As AF1 is activated via factors involved in the MAPK pathway, crosstalk exists between the ER, growth factor receptors (e.g. human epidermal growth factor receptors 1 and 2 (EGFR and HER2)) and kinase pathways (Nicholson \& Johnston 2005). ER-growth factor receptor cross-talk is thought to be involved in the development of resistance to endocrine therapy by reducing the reliance on oestrogen-sensitive proliferation. As such, inhibition of growth factor receptor pathways, particularly in conjunction with inhibition 
of ER signalling, may provide additional ways of circumventing endocrine resistance (Nicholson \& Johnston 2005).

\section{'Non-genomic' actions of oestradiol}

In addition to the classical action of ER as a ligandregulated transcription factor, oestradiol also exerts early signalling events within target cells minutes after stimulation, making it likely that these effects are independent of transcription. These processes may be mediated by membrane-associated ER (Hanstein et al. 2004) or the G-coupled membrane receptor GPR30 (Filardo \& Thomas 2005). Activation of membraneassociated ER has been shown to lead to activation of MAPK signalling, phosphatidylinositol-3-kinase (PI-3K) signalling and a rise in cytoplasmic calcium levels. It can also activate release of epithelial growth factor (EGF) and insulin-like growth factor (IGF), thus leading to stimulation of EGFR and IGFR, respectively (Hanstein et al. 2004). GPR30 can act independently of $\mathrm{ER} \alpha$ and $\mathrm{ER} \beta$ and has been linked to oestrogenmediated regulation of the EGFR to MAPK signalling axis via stimulation of adenylyl cyclase activity (Filardo et al. 2000, 2002, Filardo \& Thomas 2005).

\section{Effect of partial oestrogen antagonists upon oestrogen signalling}

Even though the affinity of tamoxifen for the ER is $2.5 \%$ that of oestradiol (Wakeling \& Bowler 1987, Wakeling et al. 1991), tamoxifen has similar molecular effects to oestradiol once bound to the ER (Katzenellenbogen et al. 1996) (i.e. increased nuclear translocation and ERE binding of the tamoxifen-ER complex). This may be due to the fact that the major mediator of tamoxifen action is 4-hydroxy-tamoxifen, which has been shown to have a similar affinity for the ER as oestradiol (Borgna \& Rochefort 1980). Tamoxifen, idoxifene and raloxifene have all been shown to increase ER $\alpha$ protein and mRNA levels in MCF-7 cells (Wijayaratne et al. 1999), possibly as a result of their oestrogen agonist activity.

The gene-specific actions of partial oestrogen antagonists such as tamoxifen, toremifene and raloxifene (all of which are non-steroidal in structure) can be accounted for by several factors, including ligand affinity and differences in ER conformation, and differences in the efficiency of coactivators and corepressors coupling to the transcriptional complex Katzenellenbogen et al. 1996). While AF2 is inactivated in the tamoxifen-ER complex, AF1-mediated transcription is unaffected by tamoxifen. The partial agonism observed with tamoxifen is attributed to AF1 activity, which itself is dependent upon cellular and promoter factors (Berry et al. 1990, Tzukerman et al. 1994). Other SERMs such as idoxifene and raloxifene also inhibit ER AF2 but show partial agonist activity against AF1 in MCF-7 cells (Wijayaratne et al. 1999). However, not all of the biological effects of partial oestrogen antagonists may be explained by their ability to differentially regulate $\mathrm{AF} 1$ and $\mathrm{AF} 2$, as other $\mathrm{AF}$ domains may also exist that only function when AF1 and AF2 are inactive. Indeed, an autonomous activation domain, referred to as AF2a, has already been described (Norris et al. 1997), although the impact of partial oestrogen antagonists on this domain remains unclear. Thus, the effects of these agents are likely to be cell, promoter and effector sensitive, which may explain their differential actions on bone, the cardiovascular system and the uterus.

Although $\mathrm{ER} \alpha$ and $\mathrm{ER} \beta \mathrm{AF} 1$ generally exhibit weak activity at genes with classical EREs, there are certain cellular environments in which differential effects of SERMs on AF1 activity at EREs are detectable. In such situations, tamoxifen-bound ER $\alpha$ has similar activity to unbound $\mathrm{AF} 1$ and raloxifene-bound $\mathrm{ER} \alpha$ has less activity. When bound by the pure antioestrogen, ICI $164,384, \mathrm{ER} \alpha$ has no activity at all. These differences appear to be due to differential recruitment of corepressors (Webb et al. 2003). Other oestrogen agonist effects of SERMs stem from ER activity at genes with alternate response elements. For example, $\mathrm{ER} \alpha$ enhances AP1 activity in the presence of tamoxifen and shows weaker activity in the presence of raloxifene (Paech et al. 1997). SERMs can also enhance AP1 activity via an AF-independent mechanism; here, raloxifene strongly enhances ER $\alpha$ action whereas tamoxifen does not (Webb et al. 2003). Therefore, SERMs differentially regulate two mechanisms of ER action at AP1 sites.

\section{Effect of pure oestrogen antagonists upon oestrogen signalling}

Fulvestrant is a $7 \alpha$-alkylsulphinyl analogue of $17 \beta$ oestradiol that is structurally distinct from the nonsteroidal oestrogen antagonists. The $\mathrm{C} 7$ side chain of fulvestrant is crucial for its mode of action; it differentiates fulvestrant from oestradiol, and its position, length and flexibility determine the pure antagonistic activity of fulvestrant (Bowler et al. 1989). This chemical structure is also responsible for the important differences between fulvestrant and tamoxifen. First, the binding affinity of fulvestrant to the ER is $89 \%$ that of oestradiol (Wakeling \& Bowler 1987). Secondly, the conformational change induced by 
fulvestrant binding means that ER homodimerisation and energy-dependent nuclear-cytoplasmic shuttling is prevented, blocking nuclear localisation of the ER (Fawell et al. 1990, Dauvois et al. 1993). In addition, cellular levels of ER are decreased via several mechanisms: turnover is increased, half-life is decreased and there is rapid ER degradation (Fawell et al. 1990, Dauvois et al. 1992, Wijayaratne et al. 1999).

Fulvestrant also disables both $\mathrm{AF} 1$ and $\mathrm{AF} 2$ on $\mathrm{ER} \alpha$; thus, even if any fulvestrant-ER complexes are present in the nucleus, gene transcription is abrogated, despite the fact that the fulvestrant-ER complex binds DNA (Wijayaratne et al. 1999). As mentioned previously, when ER $\alpha$ is bound to the pure antioestrogen, ICI 164,384, no AF1 activity is detectable at classical EREs (Webb et al. 2003). Fulvestrant has been shown to inhibit ER $\alpha$-mediated transcription from an ERE in MCF-7 cells more effectively than tamoxifen, raloxifene or idoxifene (Wijayaratne et al. 1999). In contrast to tamoxifen, pure antioestrogens can strongly enhance $\mathrm{ER} \alpha$ activity at AP1 sites via an AF-independent mechanism (Webb et al. 2003). A recent cDNA microarray study has also highlighted the differences in levels of ER antagonism between fulvestrant and the SERMs (Frasor et al. 2004). Here, fulvestrant was shown to antagonise the expression of $95 \%$ of oestrogen-upregulated genes and $91 \%$ of oestrogendownregulated genes. In contrast, tamoxifen antagonised expression of only $47 \%$ of oestrogenupregulated genes and $26 \%$ of oestrogen-downregulated genes. The antagonistic activity of raloxifene was somewhere in between, being $67 \%$ for oestrogenupregulated and $33 \%$ for oestrogen-downregulated genes. Conversely, only tamoxifen had full agonistic activity on a substantial proportion of genes; $23 \%$ of those upregulated by oestrogen and $31 \%$ of those downregulated. In contrast, fulvestrant and raloxifene had full agonistic activity on $\leq 8 \%$ of oestrogenregulated genes overall (Frasor et al. 2004).

Fulvestrant has also been shown to affect rapid, 'nongenomic' oestrogen signalling via membraneassociated ER. Activation of the MAPK pathway via oestrogen stimulation of membrane-associated ER is abolished by fulvestrant in vitro; however, activation of MAPK via EGF is unaffected (Improta-Brears et al. 1999). Interestingly, as seen with oestrogen, both fulvestrant and tamoxifen have been shown to activate GPR30-mediated stimulation of adenylyl cyclase, leading to cAMP-mediated inhibition of Erk-1 and Erk-2 and the attenuation of the EGFRMAPK signalling cascade (Filardo et al. 2000, 2002).
Fulvestrant may help to circumvent hormone resistance via pathways of receptor cross-talk by reducing cellular ER levels (Hutcheson et al. 2003). Indeed, one major difference between fulvestrant and tamoxifen is the ability of fulvestrant to abrogate ER activation mediated by other signalling factors, such as EGFR, IGFR and dopamine (Ignar-Trowbridge et al. 1993, Smith et al. 1993, Newton et al. 1994). In contrast, tamoxifen is unable to block the activation of ER by the same mediators (Ignar-Trowbridge et al. 1993, Smith et al. 1993, Newton et al. 1994).

\section{Biological effects of pure oestrogen antagonists}

There is extensive preclinical data to support the pure oestrogen antagonist effects of fulvestrant. In vitro, fulvestrant significantly decreased ER protein levels and inhibited PgR expression in MCF-7 cells (McClelland et al. 1996). In contrast, tamoxifen increased MCF-7 ER (oestrogen withdrawal has a similar effect) and PgR protein levels (Horowitz \& McGuire 1978, Nicholson et al. 1995, Early Breast Cancer Trialists' Collaborative Group 1998, Hutcheson et al. 2003). In vivo, a single $5 \mathrm{mg}$ dose of fulvestrant (short-acting formulation) was as effective as tamoxifen $(10 \mathrm{mg} / \mathrm{kg} /$ day orally) in blocking the growth of MCF-7 xenografts in nude mice (Wakeling et al. 1991). In addition, fulvestrant (5 $\mathrm{mg}$ weekly) suppressed the growth of established MCF-7 xenografts in mice for twice as long as tamoxifen $(500 \mu \mathrm{g} /$ day $)$ or oestrogen withdrawal, and was more effective than tamoxifen in reducing the expression of oestrogen-regulated genes in MCF-7 xenograft tissue (Osborne et al. 1995).

The effect of short-term administration of fulvestrant on breast cancer was initially evaluated in 56 women with primary breast cancer who were randomised to receive no preoperative treatment $(n=16)$ or daily i.m. fulvestrant $(n=37$ (6 mg, $n=21 ; 18 \mathrm{mg}, n=16)$ ) for 7 days prior to primary breast surgery (DeFriend et al. 1994). There was no evidence of agonist activity using fulvestrant, which significantly reduced tumour ER (median ER index, 0.72 before vs 0.02 after treatment; $P<0.001$ ), PgR (median PgR index, 0.50 before vs 0.01 after treatment; $P<0.05$ ) and Ki67 (median Ki67 labelling index, 3.2 before vs 1.1 after treatment; $P<0.05$ ) expression levels (DeFriend et al. 1994). More recently in the preoperative setting, 201 postmenopausal women with stage T1-3 breast cancer were treated with fulvestrant $(50 \mathrm{mg}, 125 \mathrm{mg}$ or $250 \mathrm{mg}$ on day 0 as an i.m. injection), tamoxifen $(20 \mathrm{mg} /$ day orally) or tamoxifen placebo for 14-21 days prior to surgery of curative intent (Robertson et al. 2001). Tumour biopsies (taken at 
baseline and during surgery 15-22 days after dosing) were analysed for ER and PgR levels (H-score), proliferation (Ki67 levels) and apoptosis markers. ER levels were significantly decreased by tamoxifen when compared with placebo $(P=0.049)$ and by all doses of fulvestrant compared with placebo $(P<0.026)$ (Fig. 2). In addition, ER levels were significantly decreased by $250 \mathrm{mg}$ fulvestrant compared with tamoxifen $(P=0.024)$. While tamoxifen significantly increased $\mathrm{PgR}$ levels compared with placebo $(P=0.009)$, fulvestrant, $125 \mathrm{mg}$ and $250 \mathrm{mg}$, significantly reduced $\mathrm{PgR}$ levels compared with either placebo or tamoxifen $(P \leq 0.003)$. Although, fulvestrant and tamoxifen significantly reduced proliferation compared with placebo $(P<0.046$ for both), none of the treatment arms affected apoptotic indices (Robertson et al. 2001). The differential effects on PgR levels observed highlight the 'pure' oestrogen antagonist effects of fulvestrant. A more recent study has analysed the effect of long-term pre- and postoperative fulvestrant $(250 \mathrm{mg} / \mathrm{month})$ on ER expression in patients with locally advanced or metastatic breast cancer (Robertson et al. 2004). Nineteen out of 24 patients experienced clinical benefit (CB), and this group had a significant reduction in tumour ER levels after 4-6 weeks and 6 months of treatment compared with pretreatment levels $(P=0.029$ and $P=0.011$ respectively). In contrast, ER levels were not significantly reduced in the five patients with progressive disease (PD) at the 4-6 weeks time point (Robertson et al. 2004). Thus, fulvestrant can maintain ER suppression for a sustained period (beyond 6 months), and downregulation may be higher in those experiencing $\mathrm{CB}$ than those with de novo progression. The presence of tumour ER in all patients at the time of progression supports the use of further endocrine therapy after fulvestrant.

Moreover, ER expression in patients with PD might provide insights into mechanisms of resistance through growth factor receptor cross-talk. The amount of crossresistance observed between tamoxifen and the newer partial antagonists being developed was a major problem. Importantly, cross-resistance between fulvestrant and tamoxifen has not been observed in vitro; fulvestrant is a far more potent inhibitor of tamoxifen-sensitive and tamoxifen-resistant MCF-7 proliferation $(\sim 150$ and 1540 times more potent than tamoxifen respectively) (Hu et al. 1993), and tamoxifen inhibits both fulvestrantsensitive and fulvestrant-resistant MCF-7 cell lines (Lykkesfeldt et al. 1995). In vivo, the growth of tamoxifen-resistant MCF-7 xenografts in nude mice (generated following treatment with $500 \mu \mathrm{g} /$ day tamoxifen for 6 months) was abrogated by fulvestrant (5 mg/week) (Osborne et al. 1994). These data suggested that fulvestrant had potential in the treatment of patients with tamoxifen-resistant tumours.

\section{Lack of agonist effects}

Despite the fact that tamoxifen is well tolerated, the risks of thromboembolic disease and endometrial

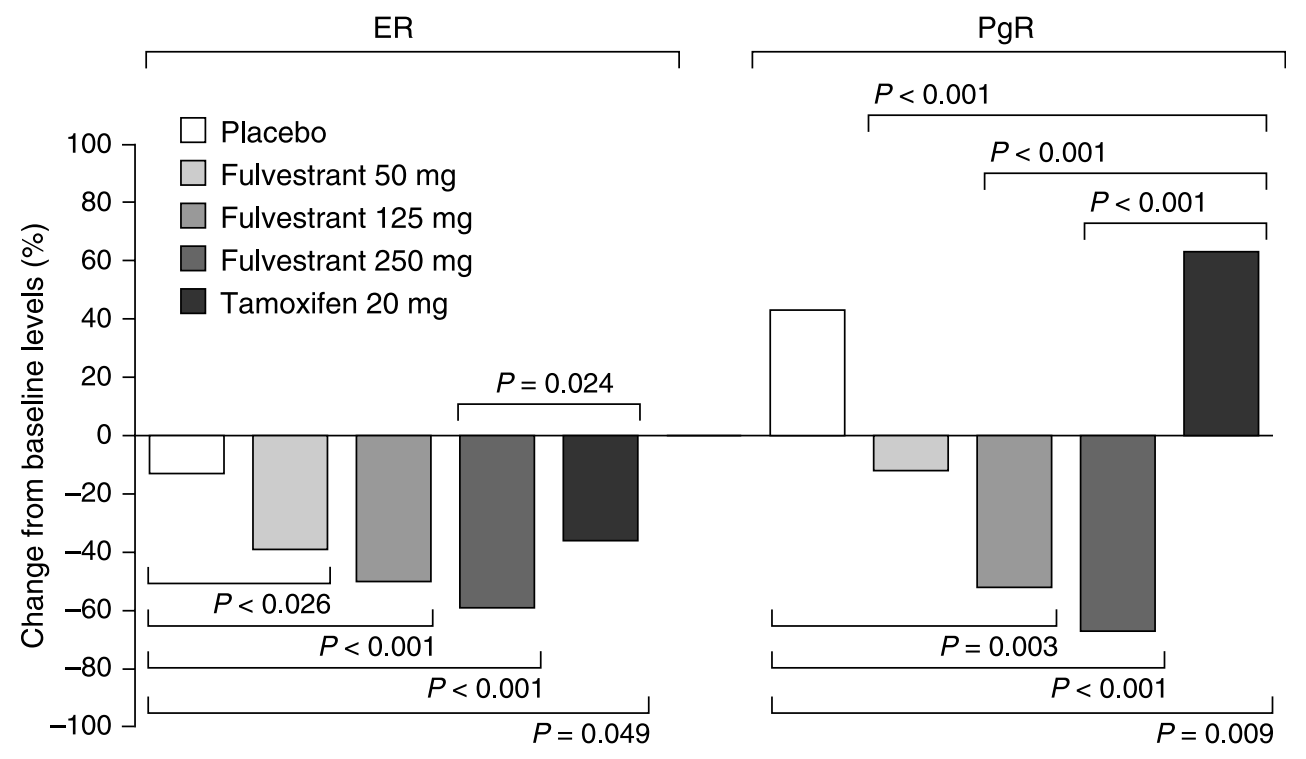

Figure 2 Percentage change in tumour oestrogen receptor $(E R)$ and progesterone receptor $(\mathrm{PgR})$ levels using short-term fulvestrant in patients with ER-positive and PgR-positive tumours. Biopsies were taken prior to treatment and during surgical excision 15-22 days later. Based on data in Robertson et al. (2001). 
cancer increase with long-term use due to partial agonist activity (Fisher et al. 1994, 1996, Early Breast Cancer Trialists' Collaborative Group 1998). In contrast, a wealth of preclinical and clinical data show that the pure oestrogen antagonist fulvestrant lacks these partial agonist effects.

In vivo, fulvestrant $(0.03-1.0 \mathrm{mg} / \mathrm{kg} /$ day for 14 days $)$ inhibited the uterotrophic effect of oestradiol $(0.5 \mu \mathrm{g})$ or tamoxifen $(1 \mathrm{mg} / \mathrm{kg})$ in immature or ovariectomised rodents in a dose-dependent manner (Wakeling et al. 1991). In contrast, tamoxifen only partially blocked the uterotrophic activity of oestradiol (Wakeling et al. 1991). Fulvestrant (4 mg short-acting formulation) also inhibited oestradiol-induced increases in endometrial volume in ovariectomised primates to below that present at the start of the menstrual cycle (Dukes et al. 1993). Moreover, the rate and extent of endometrial involution were similar to that observed following oestradiol withdrawal, demonstrating a lack of oestrogen-agonist effects (Dukes et al. 1993). In both of these animal models, fulvestrant was not associated with the uterine hyperplasia often observed with tamoxifen treatment.

These preclinical data have been supported by data from a study in healthy volunteers. In a phase I trial, 30 healthy postmenopausal women received a single dose i.m. $125 \mathrm{mg}$ or $250 \mathrm{mg}$ fulvestrant or placebo, followed 2 weeks later by $20 \mu \mathrm{g} /$ day ethinyloestradiol for 2 weeks (Addo et al. 2002). No evidence of agonist activity in the endometrium was observed. Moreover, $250 \mathrm{mg}$ fulvestrant abrogated the mean change in oestrogen-stimulated endometrial thickening after 21 days of treatment $(1.5 \mathrm{~mm}$ vs $8.1 \mathrm{~mm} ; P<0.001)$ (Addo et al. 2002). Thus, fulvestrant lacks oestrogen agonist activity on the normal human postmenopausal endometrium.

\section{Clinical efficacy of pure oestrogen antagonists}

\section{In tamoxifen-resistant advanced breast cancer}

Preclinical data suggesting that fulvestrant may be beneficial in the treatment of tamoxifen-resistant tumours (Hu et al. 1993, Osborne et al. 1994) have been supported by the efficacy of fulvestrant in patients with this type of breast cancer. In a small, initial clinical study $(n=19)$, over two-thirds (69\%) of postmenopausal women with tamoxifen-resistant disease treated with fulvestrant experienced CB (Howell et al. 1996). Moreover, a long duration of response (DoR) was observed in these women (median duration 25 months) (Howell \& Robertson 1995, Howell et al. 1996), supporting preclinical evidence that fulvestrant suppressed tumour growth for longer than tamoxifen (Osborne et al. 1995). Thus, fulvestrant was shown not to be cross-resistant with tamoxifen in the clinical setting.

These data were confirmed more recently in two phase III trials in postmenopausal women with advanced breast cancer who previously had progressed after receiving anti-oestrogen treatment (Howell et al. 2002, Osborne et al. 2002). Both studies had a similar design, in which fulvestrant ( $250 \mathrm{mg} / \mathrm{month}$ i.m., $n=428$ ) was compared with the aromatase inhibitor (AI) anastrozole $(1 \mathrm{mg} /$ day orally, $n=423$ ). In one study, fulvestrant was administered as a single $5 \mathrm{ml}$ injection in an open-label comparison (International), whereas in the other study fulvestrant was administered as two separate $2.5 \mathrm{ml}$ injections in a double-blind comparison (North American). The results of a prospectively designed, combined analysis of these studies are presented here.

Most patients in the fulvestrant and anastrozole groups had progressed following previous treatment with tamoxifen (96 vs $97 \%$ respectively), and both groups were generally well matched at baseline for age, weight, prior therapy, hormone receptor status and extent of metastatic or recurrent disease (Robertson et al. 2003). At median follow-up of 15.1 months, the median time to progression (TTP) (Fig. 3) was comparable in both groups (5.5 vs 4.1 months for fulvestrant and anastrozole respectively; hazard ratio (HR) 0.95; 95.14\% confidence interval (CI) 0.82, 1.10; $P=0.48$ ). The objective response (OR; complete response $(\mathrm{CR})+$ partial response $(\mathrm{PR}))$ rate was not significantly different between the two groups, being $19.2 \%$ in the fulvestrant group compared with $16.5 \%$ in

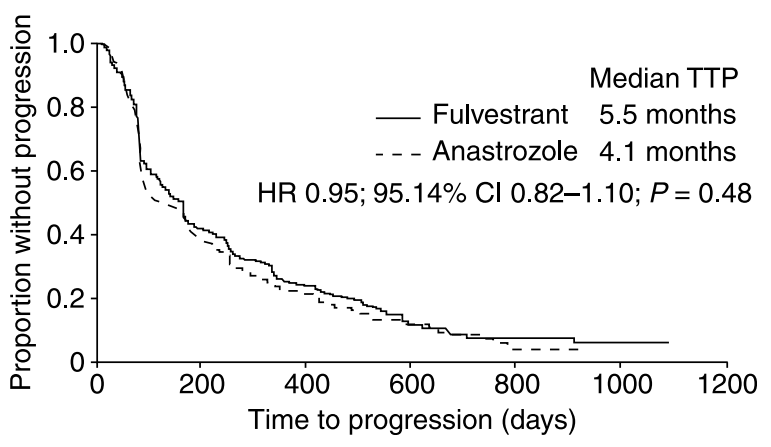

Figure 3 Kaplan-Meier plot for time to progression (TTP) in patients who had previously progressed on endocrine antioestrogen therapy: fulvestrant vs anastrozole in advanced breast cancer. Robertson JF, Osborne CK, Howell A, Jones SE, Mauriac L, Ellis M, Kleeberg UR, Come SE, Vergote I, Gertler S et al. 2003 Fulvestrant versus anastrozole for the treatment of advanced breast carcinoma in postmenopausal women: a prospective combined analysis of two multicenter trials. Cancer 98 229-238. Copyright (C) 2003 American Cancer Society.

Reprinted by permission of Wiley-Liss, Inc., a subsidiary of John Wiley \& Sons, Inc. 
the anastrozole group $(P=0.31)$. In addition, there were no differences in OR rates between fulvestrant and anastrozole in the subgroup of patients who had any visceral metastases (15.7 vs $13.2 \%$ respectively; $P=0.49)$ or those with visceral metastases only (18.8 vs $14.0 \%$ respectively; $P=0.43$ ) (Mauriac et al. 2003). Furthermore, fulvestrant demonstrated similar efficacy in patients with/without visceral metastases.

In patients who had an OR, further follow-up was performed at a median of 22.1 months (Robertson et al. 2003). The median DoR was 16.7 and 13.7 months in those patients who responded to fulvestrant $(n=84)$ and anastrozole $(n=73)$ respectively (Fig. 4); mean duration of response was significantly greater for fulvestrant than anastrozole (HR 1.30; 95\% CI 1.13, 1.50; $P<0.01$ ) (Robertson et al. 2003). A similar proportion of patients experienced $\mathrm{CB}(\mathrm{OR}+$ stable disease (SD) for $\geq 24$ weeks; $43.5 \%$ patients receiving fulvestrant and $40.9 \%$ patients receiving anastrozole) and the median duration of $\mathrm{CB}$ was also similar between the groups (11.8 vs 11.2 months respectively).

A survival analysis conducted at a median follow-up of 27.0 months showed that the overall survival was very similar with fulvestrant and anastrozole (median 27.4 vs 27.7 months respectively; HR 0.98 ; $95 \%$ CI $0.84,1.15 ; P=0.809)$, and that three-quarters of the patients had died in each group (74.5 vs $76.1 \%$ respectively) (Howell et al. 2005). Indeed, as the upper $95 \%$ CI was below the predefined limit of 1.25 , fulvestrant may be considered non-inferior to anastrozole in terms of overall survival benefit.

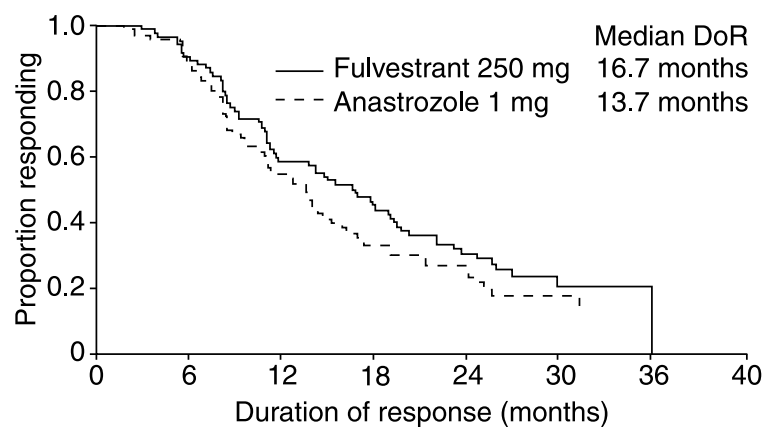

Figure 4 Kaplan-Meier plot for duration of response (DoR) from randomisation to disease progression in responding patients: fulvestrant vs anastrozole in advanced breast cancer. Robertson JF, Osborne CK, Howell A, Jones SE, Mauriac L, Ellis M, Kleeberg UR, Come SE, Vergote I, Gertler S et al. 2003 Fulvestrant versus anastrozole for the treatment of advanced breast carcinoma in postmenopausal women: a prospective combined analysis of two multicenter trials. Cancer 98 229-238. Copyright (C) 2003 American Cancer Society. Reprinted by permission of Wiley-Liss, Inc., a subsidiary of John Wiley \& Sons, Inc.

\section{As first-line therapy for advanced breast cancer}

The efficacy of first-line fulvestrant vs tamoxifen has been investigated in postmenopausal women with metastatic or locally advanced breast cancer. In a phase III study, endocrine-naïve patients or patients who had completed endocrine therapy $\geq 1$ year previously were treated with either fulvestrant ( $250 \mathrm{mg} / \mathrm{month}$ i.m. injection with placebo tamoxifen, $n=313)$ or tamoxifen $(20 \mathrm{mg} /$ day orally with placebo fulvestrant, $n=274$ ) (Howell et al. 2004). Approximately $20-25 \%$ of patients had received prior adjuvant tamoxifen therapy for their primary breast cancer.

After a median follow-up of 14.5 months, there was no significant difference between fulvestrant and tamoxifen for the primary endpoint TTP (median 6.8 vs 8.3 months respectively; HR 1.18; $95 \%$ CI 0.98 , 1.44; $P=0.088$; Table 1). OR rates were similar between the two arms (31.6\% for fulvestrant vs $33.9 \%$ for tamoxifen); however, $\mathrm{CB}$ rates were significantly higher in the tamoxifen group (54.3\% for fulvestrant vs $62.0 \%$ for tamoxifen; $P=0.026$ ). In patients experiencing an OR, the median DoR was similar (17.3 vs 19.8 months with fulvestrant and tamoxifen respectively) (Howell et al. 2004). Thus, in the overall (intent-totreat (ITT)) population between-group differences in efficacy favoured tamoxifen and the statistical noninferiority of fulvestrant could not be demonstrated.

Table 1 Impact of hormone receptor status on time to progression with fulvestrant vs tamoxifen in patients with advanced breast cancer (Howell A, Robertson JFR, Abram P, Lichinister MR, Elledge R, Bajetta E, Watanabe T, Morris C, Webster A, Dimery I et al. 2004 Comparison of fulvestrant vs tamoxifen for the treatment of advanced breast cancer in postmenopausal women previously untreated with endocrine therapy: a multi national, double blind, randomized trial. Journal of Clinical Oncology 22 1605-1613. Reprinted with permission from the American Society of Clinical Oncology.)

\begin{tabular}{lcccc}
\hline $\begin{array}{l}\text { Patient } \\
\text { population }\end{array}$ & $\boldsymbol{n}(\%)$ & HR & $\mathbf{9 5 \%} \mathbf{C l}$ & $\boldsymbol{P}$-value \\
\hline $\begin{array}{l}\text { ITT } \\
\quad \text { Fulvestrant }\end{array}$ & $313(100)$ & 1.18 & $0.98,1.44$ & 0.088 \\
$\quad$ Tamoxifen & $274(100)$ & & & \\
$\begin{array}{l}\text { ER }+ \text { and/or PgR+ } \\
\quad \text { Fulvestrant }\end{array}$ & $247(78.9)$ & 1.10 & $0.89,1.36$ & 0.39 \\
$\quad$ Tamoxifen & $212(77.4)$ & & & \\
ER + and PR+ & & & & \\
$\quad$ Fulvestrant & $131(41.9)$ & 0.85 & $0.63,1.15^{*}$ & 0.31 \\
$\quad$ Tamoxifen & $114(41.6)$ & & & \\
\hline
\end{tabular}

$\mathrm{HR}$, hazard ratio; $\mathrm{Cl}$, confidence interval; ITT, intent-to-treat; $\mathrm{ER}+$, oestrogen receptor positive; $\mathrm{PgR}+$, progesterone receptor positive.

*Non-inferiority of fulvestrant to tamoxifen is shown by an upper $95 \% \mathrm{Cl}$ of $\leq 1.25$. 
The ITT population contained $>20 \%$ of patients for whom the ER status was negative or unknown. Given the modes of action of tamoxifen and fulvestrant, patients with hormone receptor-positive breast tumours may be expected to gain the greatest benefit from these drugs. In a prospectively planned analysis of those patients with ER-positive and/or PgR-positive breast tumours ( $>75 \%$ of patients), median TTP was similar between fulvestrant and tamoxifen (8.2 vs 8.3 months respectively; HR 1.10; 95\% CI $0.89,1.36 ; P=0.39$; Table 1, Fig. 5) (Howell et al. 2004). Furthermore, similar rates for CB (57.1 vs $62.7 \%$; HR $0.79 ; 95 \%$ CI $15.01,3.19 ; P=0.22)$ and $\mathrm{OR}(33.2$ vs $31.1 \%$; HR 1.10 ; $95 \%$ CI $0.74,1.63 ; P=0.64)$ were observed in the fulvestrant and tamoxifen groups respectively. Therefore, in patients with hormone receptor-positive tumours, fulvestrant and tamoxifen had similar efficacy.

In an additional post-hoc analysis of patients with breast tumours that were positive for both ER and $\mathrm{PgR}$ ( $\sim 42 \%$ of patients), the findings for median TTP were again shown to be comparable in the two groups (11.4 vs 8.5 months for fulvestrant and tamoxifen respectively; HR $0.85 ; 95 \%$ CI 0.63, 1.15; $P=0.31$; Table 1) (Buzdar 2004). Further studies of first-line fulvestrant are warranted, specifically in patients with confirmed hormone receptorpositive breast tumours, as these patients represent the intended treatment population for the drug.

\section{Experience from a compassionate-use programme}

Treatment options are severely limited in postmenopausal women with advanced breast cancer who

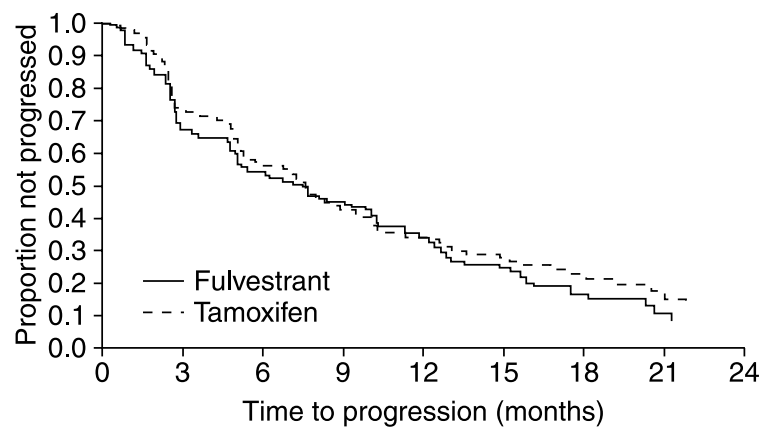

Figure 5 Kaplan-Meier plot for time to progression (TTP) in patients with ER-positive and/or PgR-positive tumours: fulvestrant vs tamoxifen in advanced breast cancer. Howell A, Robertson JF, Abram P, Lichinitser MR, Elledge R, Bajetta R, Watanabe T, Morris C, Webster A, Dimery I \& Osborne CK 2004 Comparison of fulvestrant versus tamoxifen for the treatment of advanced breast cancer in postmenopausal women previously untreated with endocrine therapy: a multinational, double-blind, randomised trial. Journal of Clinical Oncology 22 1605-1613. Reprinted with permission from the American Society of Clinical Oncology. have received multiple prior therapies (endocrine or chemotherapy). For patients who were not eligible to receive fulvestrant as part of a clinical trial and in countries where fulvestrant was not yet approved, fulvestrant was available as part of a compassionateuse programme (Franco et al. 2004, Petruzelka et al. 2004, Steger et al. 2005).

In the largest report from a single centre, data are available from 126 patients $(80 \%$ had received fulvestrant as second- or third-line endocrine therapy and $60 \%$ had received palliative chemotherapy). Of these women, $12(9.5 \%)$ had a PR and $43(34 \%)$ had $\mathrm{SD} \geq 6$ months with fulvestrant treatment resulting in a CB rate of $44 \%$ (Steger et al. 2005). Notably, 43/108 patients $(40 \%)$ who had received prior non-steroidal AI treatment gained $\mathrm{CB}$ with fulvestrant. Breast tumours were ER-positive and PgR-positive in 9/12 patients experiencing a PR and $9 / 12$ had previously received an AI. Of the 43 patients with $\mathrm{SD} \geq 6$ months in duration, 26 had ER-positive and PgRpositive tumours. Among 18 patients with HER2positive tumours, nine patients experienced SD, supporting the preclinical observation that fulvestrant can abrogate ER activation mediated by EGFR (Steger et al. 2005).

Data on the compassionate use of fulvestrant are also available from a more heavily pretreated cohort of 42 patients $(50 \%$ had received $\geq 4$ prior endocrine therapies and 38\% had received $\geq 4$ chemotherapy regimens) (Franco et al. 2004). All patients from this centre had received prior AI therapy. Despite the failure of various previous treatment options, eight patients (19\%) experienced SD for $\geq 24$ weeks; five had ER-positive and PgR-positive tumours and three had ER-positive and PgR-negative tumours. Three patients (two with ER-positive and PgR-negative tumours) had experienced SD for 14, 20 and 23+ months at the time data became available (Franco et al. 2004).

A further report has described an additional cohort of 64 pretreated patients $(78 \%$ had received fulvestrant as second- or third-line endocrine therapy and $64 \%$ had received prior chemotherapy) (Petruzelka et al. 2004). In total, 39 patients $(61 \%)$ experienced $\mathrm{CB}(\mathrm{CR}+\mathrm{PR}$ $+\mathrm{SD} \geq 24$ weeks), including five patients ( $8 \%$ ) with an OR. A durable and ongoing OR was observed in $3 / 44$ patients ( $\geq 18.5$ to $\geq 21.2$ months in duration), and 18/44 patients experienced ongoing SD of $\geq 24$ weeks ( $\geq 6.5$ to $\geq 20.3$ months). Of the five patients with an OR, three had ER-positive and PgR-positive tumours and all had received prior non-steroidal AI treatment (Petruzelka et al. 2004).

These data provide further evidence for the lack of cross-resistance of fulvestrant with other endocrine 
agents, including the AIs, and confirm that fulvestrant can provide $\mathrm{CB}$ even in heavily pretreated postmenopausal women with advanced breast cancer. Moreover, there was evidence to suggest that the use of fulvestrant earlier in the treatment sequence led to better responses. In all of these compassionate-use analyses, fulvestrant was very well tolerated.

\section{Tolerability of pure oestrogen antagonists}

Owing to its pure oestrogen antagonistic effects, fulvestrant has the potential to offer an improved tolerability profile in the treatment of postmenopausal women with advanced breast cancer compared with other endocrine agents that have less targeted efficacy. The safety and tolerability findings of phase III studies of fulvestrant, both as first-line therapy and in patients with tamoxifen-resistant disease, are described below.

In the combined analysis of the two phase III trials of patients undergoing second-line treatment with fulvestrant and anastrozole, the safety population comprised 423 patients in each group (Robertson et al. 2003). Adverse events (AEs) were generally mild to moderate in intensity. The most commonly reported AEs with fulvestrant and anastrozole respectively were nausea (26.0 vs $25.3 \%)$, asthenia (22.7 vs $27.0 \%)$, pain (18.9 vs $20.3 \%$ ), vasodilation (17.7 vs $17.3 \%$ ) and headache (15.4 vs $16.8 \%$ ). Seven predefined AEs were selected for statistical evaluation: gastrointestinal disturbances, hot flushes, joint disorders, thromboembolic disease, urinary tract infection, vaginitis and weight gain (Table 2). Of these, joint disorders was the only $\mathrm{AE}$ that was significantly different between the groups, experienced by fewer patients receiving fulvestrant (5.4 vs $10.6 \%$ with anastrozole; $P=0.0036$ ). Local injection-site reactions occurred in $1.1 \%$ of courses in patients given a single $5 \mathrm{ml}$ injection, and in $4.6 \%$ and $4.4 \%$ of courses in patients given two $2.5 \mathrm{ml}$ fulvestrant or placebo injections respectively. Only two patients (fulvestrant group) had injection-site reactions leading to withdrawal. Among patients receiving either fulvestrant or anastrozole, few patients withdrew due to AEs (2.8 vs $1.9 \%$ respectively) or drug-related AEs (0.9 vs $1.2 \%$ respectively). At longterm follow-up (median 27.0 months), no safety concerns had arisen in either treatment group (Howell et al. 2005).

In the study comparing fulvestrant and tamoxifen, the safety population comprised 310 and 271 patients, respectively, and the median follow-up was 14.5 months (Howell et al. 2004). The most commonly reported AEs in the fulvestrant and tamoxifen groups respectively, were nausea ( 20.3 vs $22.5 \%$ ), asthenia (19.4 vs $20.3 \%$ ), vasodilation (14.8 vs $21.4 \%$ ), pain (13.9 vs $19.2 \%$ ) and bone pain (13.9 vs $17.0 \%)$. Four predefined AEs (gastrointestinal disturbances, hot flushes, thromboembolic disease and vaginitis) were selected for statistical evaluation (Table 3). Of these, the incidence of hot flushes approached significance between the two groups, being lower among patients treated with fulvestrant ( 17.7 vs $24.7 \%$ with tamoxifen; $P=0.05)$. There were also fewer gastrointestinal disturbances in the fulvestrant-treated patients (37.1 vs $43.2 \%$ in the tamoxifen group), but this difference was not significant $(P=0.16)$. The incidence of thromboembolic events was higher in patients receiving fulvestrant in this study (5.8 vs $3.3 \%$ ), but not significantly so $(P=0.22)$. This apparent increase in thromboembolic events was not noted in the other phase III trials of fulvestrant (Howell et al. 2002,

Table 2 Incidence of prospectively defined adverse events in patients receiving fulvestrant or anastrozole as second-line therapy. Robertson JF, Osborne CK, Howell A, Jones SE, Mauriac L, Ellis M, Kleeberg UR, Come SE, Vergote I, Gertler S et al. 2003 Fulvestrant versus anastrozole for the treatment of advanced breast carcinoma in postmenopausal women: a prospective combined analysis of two multicenter trials. Cancer 98 229-238. Copyright (C) 2003 American Cancer Society. Reprinted by permission of Wiley-Liss, Inc., a subsidiary of John Wiley \& Sons, Inc

\begin{tabular}{|c|c|c|c|c|c|}
\hline \multirow[b]{2}{*}{ Adverse event } & \multicolumn{2}{|c|}{ Fulvestrant $(n=423)$} & \multicolumn{2}{|c|}{ Anastrozole $(n=423)$} & \multirow[b]{2}{*}{$P$-value } \\
\hline & $n$ & $\%$ & $n$ & $\%$ & \\
\hline Gastrointestinal disturbances* & 196 & 46.3 & 185 & 43.7 & 0.53 \\
\hline Hot flushes & 89 & 21.0 & 87 & 20.6 & 0.91 \\
\hline Joint disorders $†$ & 23 & 5.4 & 45 & 10.6 & 0.036 \\
\hline Thromboembolic disease & 15 & 3.5 & 17 & 4.0 & 0.68 \\
\hline Urinary tract infection & 31 & 7.3 & 18 & 4.3 & 0.06 \\
\hline Vaginitis & 11 & 2.6 & 8 & 1.9 & 0.51 \\
\hline Weight gain & 4 & 0.9 & 7 & 1.7 & 0.35 \\
\hline
\end{tabular}

*Includes patients with nausea, vomiting, constipation and haemorrhage.

†Includes patients with arthralgia, arthrosis and arthritis. 
Table 3 Incidence of prospectively defined adverse events in patients receiving fulvestrant or tamoxifen as first-line therapy. Howell A, Robertson JF, Abram P, Lichinitser MR, Elledge R, Bajetta R, Watanabe T, Morris C, Webster A, Dimery I \& Osborne CK 2004 Comparison of fulvestrant versus tamoxifen for the treatment of advanced breast cancer in postmenopausal women previously untreated with endocrine therapy: a multinational, double-blind, randomised trial. Journal of Clinical Oncology 22 1605-1613. Reprinted with permission from the American Society of Clinical Oncology

\begin{tabular}{|c|c|c|c|c|c|}
\hline \multirow[b]{2}{*}{ Adverse event } & \multicolumn{2}{|c|}{ Fulvestrant $(n=310)$} & \multicolumn{2}{|c|}{ Tamoxifen $(n=271)$} & \multirow[b]{2}{*}{$P$-value } \\
\hline & $n$ & $\%$ & $n$ & $\%$ & \\
\hline Gastrointestinal disturbances* & 115 & 37.1 & 117 & 432 & 0.16 \\
\hline Hot flushes & 55 & 17.7 & 67 & 24.7 & 0.05 \\
\hline Vaginitis & 12 & 3.9 & 17 & 6.3 & 0.26 \\
\hline Thromboembolic disease & 18 & 5.8 & 9 & 3.3 & 0.22 \\
\hline
\end{tabular}

*Includes patients with nausea, vomiting, constipation and haemorrhage.

Osborne et al. 2002) and no thromboembolic events were reported in two recent phase II studies (Ingle et al. 2004, 2006, Perey et al. 2004). Three patients receiving fulvestrant withdrew because of a drug-related $\mathrm{AE}$ (cerebrovascular accident, deep vein thrombosis and pulmonary embolus (one patient each)). No AEs leading to withdrawal were considered to be drug related in the tamoxifen group (Howell et al. 2004).

It is interesting to note that many so-called endocrine treatment-related AEs have also been noted in patients receiving placebo in breast cancer trials. For example, in the NCIC CTG MA.17 trial, postmenopausal patients receiving letrozole following 5 years of tamoxifen treatment experienced a similar frequency of oedema (17.2 vs $15.6 \%$ ), fatigue ( 29.9 vs $28.3 \%$ ), sweating (22.1 vs $20.7 \%$ ), and headache (18.1 vs $18.6 \%$ ) as placebo-treated patients (Goss et al. 2003). Therefore, it is difficult to determine which AEs are truly fulvestrant-related without the use of placebocontrolled studies.

The effects of fulvestrant on bone mineral density and markers of bone turnover are not fully elucidated, and have not yet been reported in postmenopausal women. Preclinical studies in rats suggest that fulvestrant reduces cancellous bone volume, which comprises only a small proportion of total bone (Gallagher et al. 1993, Sibonga et al. 1998) and its effects are consistent with blockade of ER-mediated bone resorption and formation (Wakeling 1995). Despite the lack of uterotrophic activity with fulvestrant, some agonistic effects on bone were apparent in the second study, which were highly dependent on circulating oestrogen levels (Sibonga et al. 1998). In a study involving 307 premenopausal women with uterine fibroids awaiting hysterectomy, fulvestrant did not produce changes in markers of bone resorption (cross-linked $\mathrm{N}$-telopeptides and free deoxypyridinoline), suggesting it did not affect bone turnover in this patient group (Donnez et al. 2003). However, the high circulating oestrogen levels in premenopausal women may have negated any impact of fulvestrant on bone turnover in this study. Further studies are required to assess any impact on bone in postmenopausal women.

\section{Future directions}

The sequential use of endocrine agents is a standard treatment strategy for advanced breast cancer. However, as non-steroidal AIs are now replacing tamoxifen as the first-line choice, the optimal sequence of endocrine therapy needs to be re-evaluated in order to maximise the benefit that patients will gain from these treatments. While direct comparisons between endocrine therapies are not always available, indirect comparisons suggest that fulvestrant offers comparable efficacy and may also have tolerability advantages over some AIs in the second-line treatment of postmenopausal women with advanced breast cancer (Dodwell $\&$ Vergote 2005). In the treatment of advanced breast cancer, third-generation AIs (e.g. anastrozole, letrozole and exemestane) have superior efficacy to tamoxifen and have become the first-line therapy of choice in this disease setting (Nabholtz et al. 2000, Mouridsen et al. 2003, Paridaens et al. 2003). Clearly, the most effective endocrine therapy should always be used first and, in cases where therapies are equally effective, the besttolerated agent should be used first. A second key consideration is that cross-resistance is less likely to occur if endocrine therapies with different modes of action are used. Finally, tumour sensitivity to subsequent endocrine therapies should be maintained.

Two large phase III trials have provided evidence that tamoxifen-resistant tumours remain sensitive to fulvestrant (Howell et al. 2002, Osborne et al. 2002). Furthermore, a phase II trial has shown that of 67 patients who developed resistance initially to tamoxifen 
and then to an AI, 28.4\% subsequently gained CB (CR $+\mathrm{PR}+\mathrm{SD} \geq 24$ weeks) with fulvestrant (median treatment duration 3.8 months) (Perey et al. 2004). Similarly, in another phase II trial of 77 patients with advanced breast cancer who had progressed on prior AI therapy (21 had also received tamoxifen), 32.5\% gained CB with fulvestrant (Ingle et al. 2004, 2006). Additionally, in the compassionate-use programme, CB was achieved in patients who received fulvestrant after progression on prior endocrine therapies, including both AIs and SERMs (Petruzelka et al. 2004, Steger et al. 2005). Importantly, tumour sensitivity to subsequent endocrine therapies appears to be maintained after fulvestrant treatment (Vergote et al. 2003, Robertson et al. 2005).

Taken together, these data position fulvestrant as a versatile agent that may be used in the second-line setting after tamoxifen, or potentially after AIs. However, initiating fulvestrant earlier in the treatment sequence may lead to better and more durable responses. Fulvestrant is now approved for the treatment of postmenopausal women with ER-positive, locally advanced or metastatic breast cancer who have either relapsed on prior adjuvant oestrogen antagonist therapy or progressed on prior oestrogen antagonist therapies. After progression on fulvestrant, endocrine therapies such as megestrol acetate or the steroidal AI exemestane may be the next appropriate drug.

Several new trials of fulvestrant are now under way to further validate its optimum position in the endocrine treatment sequence for advanced breast cancer. The Evaluation of Faslodex and Exemestane Clinical Trial (EFECT) includes postmenopausal patients with ER-positive and/or PgR-positive breast tumours who have experienced recurrence or progression on a non-steroidal AI. Patients will be randomised for double-dummy treatment with fulvestrant (loading dose: $500 \mathrm{mg}$ i.m. on day 1 and $250 \mathrm{mg}$ on day 14, plus a $250 \mathrm{mg}$ on day 28 and every month thereafter) or exemestane $(25 \mathrm{mg} /$ day orally). The primary endpoint of this study is TTP. In a second post-AI trial (Study Of Faslodex vs Exemestane with/without Arimidex (SOFEA)), postmenopausal patients with locally advanced or metastatic breast cancer (ER positive) who have recurred/progressed on treatment with non-steroidal AIs will be randomised to treatment with fulvestrant, fulvestrant plus anastrozole, or exemestane. In this study, as well as in EFECT and Faslodex and Arimidex Clinical Trial (FACT), the time to steady state of fulvestrant will be examined more closely in order to optimise loading-dose regimens. Ongoing and planned studies will also examine combination therapies, including those in which fulvestrant is co-administered with anastrozole (vs anastrozole alone in SOFEA and FACT) and the novel anti-epidermal growth factor receptor EGFR/HER2 agents gefitinib (ECOG 4101) and trastuzumab.

\section{Other pure oestrogen antagonists in development}

Although fulvestrant is the first pure oestrogen antagonist, several other pure oestrogen antagonists are undergoing preclinical development. Two new pure oestrogen antagonists, ZK-703 and ZK-253, which destabilise the $\mathrm{ER}$, have been investigated using the MCF-7 xenograft model. ZK-703 and ZK253 were not only more effective than either tamoxifen or fulvestrant at inhibiting the growth of ER-positive xenografts, they also showed a highly potent activity in tamoxifen-resistant xenografts (Hoffmann et al. 2004). Clinical studies with both of these agents are awaited with interest. Ospemifene (FC-1271a), a SERM being developed for the treatment of osteoporosis, has been observed to inhibit MCF-7 tumour growth in vivo when compared with control $(P \leq 0.05$; Taras et al. 2001), and further studies are required to evaluate its efficacy in the clinical setting. Another steroidal oestrogen antagonist that has undergone preclinical investigation with promising results is RU 58668, which has been shown to induce long-term regression of MCF-7 xenografts (van de Velde et al. 1994). These data suggest that RU 58668 may have potential for the treatment of advanced breast cancer. To date, however, there do not appear to be any clinical trials that are evaluating RU 58668 in the breast cancer setting.

Two non-steroidal fourth-generation SERMs that exert complete oestrogen antagonistic effects on the breast and uterus have been developed-acolbifene (EM-652) and its highly potent precursor EM-800 (Gauthier et al. 1997, Labrie et al. 1999). In a preclinical xenograft (ZR-75-1) study, EM-652 caused the complete disappearance of $65 \%$ of tumours and no tumours progressed (Roy et al. 2003). Moreover, 93\% of tumours that had disappeared using EM-652 did not reappear when exposed to oestrogen challenge for 12 weeks (Roy et al. 2003). Development of EM-652 is ongoing. The development of EM-800 for advanced breast cancer has been halted, despite $35 \%$ of patients $(n=43)$ with tamoxifen-resistant breast cancer who had been treated with EM-800 experiencing CB in a phase II study (Labrie et al. 2004). In comparison, $>43.5 \%$ of tamoxifen-resistant patients treated with fulvestrant experience CB (Robertson et al. 2003). 
TAS-108 is a synthetic ER ligand that blocks ER- $\alpha$ transactivation but has an agonistic effect on ER- $\beta$ (Yamamoto et al. 2005). In a phase I study in 16 patients who had received 6 to 7 prior therapies, pharmacokinetic findings were favourable and there was evidence of biological anti-tumour activity (Blakely et al. 2004). Phase II studies involving TAS-108 are planned in the USA.

\section{Conclusions}

There is a clear need for the development of oestrogen antagonistic drugs that match the clinical efficacy of tamoxifen but lack any partial agonist effects. Fulvestrant is the first 'pure' oestrogen antagonist to be extensively characterised and to enter clinical use. In postmenopausal women with advanced breast cancer, fulvestrant represents a valuable and versatile new option for endocrine therapy.

\section{Acknowledgements}

The author would like to thank Carolyn Gray, $\mathrm{PhD}$, for her editorial assistance with this manuscript.

\section{Funding}

The author declares that he has no conflicts of interest that would prejudice the impartiality of this article.

\section{References}

Addo S, Yates RA \& Laight A 2002 A phase I trial to assess the pharmacology of the new oestrogen receptor antagonist fulvestrant on the endometrium in healthy postmenopausal volunteers. British Journal of Cancer $\mathbf{8 7}$ 1354-1359.

Bardin A, Boulle N, Lazennec G, Vignon F \& Pujol P 2004 Loss of ER $\beta$ expression as a common step in estrogendependent tumor progression. Endocrine-Related Cancer 11 537-551.

Beato M 1989 Gene regulation by steroid hormones. Cell $\mathbf{5 6}$ 335-344.

Berry M, Metzger D \& Chambon P 1990 Role of the two activating domains of the oestrogen receptor in the cell-type and promoter-context dependent agonistic activity of the anti-oestrogen 4-hydroxytamoxifen. EMBO Journal 9 2811-2818.

Blakely LJ, Buzdar A, Chang HY, Frye D, Theriault R, Valero V, Rivera E, Booser D, Kuritani J \& Tsuda M 2004 A phase I and pharmacokinetic study of TAS-108 in postmenopausal female patients with locally advanced, locally recurrent inoperable, or progressive metastatic breast cancer. Clinical Cancer Research 10 5425-5431. Borgna JL \& Rochefort H 1980 High-affinity binding to the estrogen receptor of $\left[{ }^{3} \mathrm{H}\right] 4$-hydroxytamoxifen, an active antiestrogen metabolite. Molecular and Cellular Endocrinology 20 71-85.

Bowler J, Lilley TJ, Pittam JD \& Wakeling AE 1989 Novel steroidal pure antiestrogens. Steroids 54 71-99.

Brzozowski AM, Pike AC, Dauter Z, Hubbard RE, Bonn T, Engstrom O, Ohman L, Greene GL, Gustafsson JA \& Carlquist M 1997 Molecular basis of agonism and antagonism in the oestrogen receptor. Nature $\mathbf{3 8 9}$ 753-758.

Buzdar AU 2004 Fulvestrant: a new type of estrogen receptor antagonist for the treatment of advanced breast cancer. Drugs Today (Barc) 40 751-764.

Buzdar AU, Marcus C \& Holmes F 1988 Phase II evaluation of LY156758 in metastatic breast cancer. Oncology 45 344-345.

Buzdar A, Hayes D, El-Khoudary A, Yan S, Lønning P, Lichinitser M, Gopal R, Falkson G, Pritchard K, Lipton A et al. 2002 Phase III randomized trial of droloxifene and tamoxifen as first-line endocrine treatment of ER/PgRpositive advanced breast cancer. Breast Cancer Research and Treatment 73 161-175.

Buzdar A, O’Shaughnessy JA, Booser DJ, Pippen JE Jr, Jones SE, Munster PN, Peterson P, Melemed AS, Winer E \& Hudis C 2003 Phase II, randomized, double-blind study of two dose levels of arzoxifene in patients with locally advanced or metastatic breast cancer. Journal of Clinical Oncology 21 1007-1014.

Cheskis BJ, Karathanasis S \& Lyttle CR 1997 Estrogen receptor ligands modulate its interaction with DNA. Journal of Biological Chemistry 272 11384-11391.

Chinenov Y \& Kerppola TK 2001 Close encounters of the many kinds: Fos:Jun interactions that mediate transcription regulatory specificity. Oncogene $\mathbf{2 0}$ 2438-2452.

Cotreau MM, Stonis L, Dykstra KH, Gandhi T, Gutierrez M, Xu J, Park Y, Burghart PH \& Schwertschlag US 2002 Multiple-dose, safety, pharmacokinetics, and pharmacodynamics of a new selective estrogen receptor modulator, ERA-923, in healthy postmenopausal women. Journal of Clinical Pharmacology 42 157-165.

Cuzick J, Powles T, Veronesi U, Forbes J, Edwards R, Ashley S \& Boyle P 2003 Overview of the main outcomes in breast-cancer prevention trials. Lancet 361 296-300.

Dauvois S, Danielian PS, White R \& Parker MG 1992 Antiestrogen ICI 164,384 reduces cellular estrogen receptor content by increasing its turnover. PNAS 89 4037-4041.

Dauvois S, White R \& Parker MG 1993 The antiestrogen ICI 182780 disrupts estrogen receptor nucleocytoplasmic shuttling. Journal of Cell Science 106 1377-1388.

DeFriend DJ, Howell A, Nicholson RI, Anderson E, Dowsett M, Mansel RE, Blamey RW, Bundred NJ, Robertson JF, Saunders C et al. 1994 Investigation of a new pure antiestrogen (ICI 182,780) in women with primary breast cancer. Cancer Research 54 408-414. 
Delmas PD, Bjarnason NH, Mitlak BH, Ravoux AC, Shah AS, Huster WJ, Draper M \& Christiansen C 1997 Effects of raloxifene on bone mineral density, serum cholesterol concentrations, and uterine endometrium in postmenopausal women. New England Journal of Medicine 337 1641-1647.

Dodwell D \& Vergote I 2005 A comparison of fulvestrant and third-generation aromatase inhibitors in the second-line treatment of postmenopausal women with advanced breast cancer. Cancer Treatment Reviews 31 274-282.

Donnez J, Hervais Vivancos B, Kudela M, Audebert A \& Jadoul P 2003 A randomized, placebo-controlled, doseranging trial comparing fulvestrant with goserelin in premenopausal patients with uterine fibroids awaiting hysterectomy. Fertility and Sterility 79 1380-1389.

Dukes M, Waterton JC \& Wakeling AE 1993 Antiuterotrophic effects of the pure antioestrogen ICI 182,780 in adult female monkeys (Macaca nemestrina): quantitative magnetic resonance imaging. Journal of Endocrinology 138 203-210.

Early Breast Cancer Trialists' Collaborative Group 1998 Tamoxifen for early breast cancer: an overview of the randomised trials. Lancet 351 1451-1467

Evans RM 1988 The steroid and thyroid hormone receptor superfamily. Science 240 889-895.

Fawell SE, White R, Hoare S, Sydenham M, Page M \& Parker MG 1990 Inhibition of estrogen receptor-DNA binding by the "pure" antiestrogen ICI 164,384 appears to be mediated by impaired receptor dimerization. Proceedings of the National Academy of Sciences USA 87 6883-6887.

Filardo EJ \& Thomas P 2005 GPR30: a seven-transmembrane-spanning estrogen receptor that triggers EGF release. Trends in Endocrinology and Metabolism 16 362-367.

Filardo EJ, Quinn JA, Bland KI \& Frackelton AR Jr 2000 Estrogen-induced activation of ERk-1 and ERk-2 requires the G protein-coupled receptor homolog, GPR30, and occurs via trans-activation of the epidermal growth factor receptor through release of EGF. Molecular Endocrinology 14 1649-1660.

Filardo EJ, Quinn JA, Frackelton AR Jr \& Bland KI 2002 Estrogen action via the $\mathrm{G}$ protein-coupled receptor, GPR30: stimulation of adenylyl cyclase and cAMPmediated attenuation of the epidermal growth factor receptor-to-MAPK signaling axis. Molecular Endocrinology 16 70-84.

Fisher B, Costantino JP, Redmond CK, Fisher ER, Wickerham DL \& Cronin WM 1994 Endometrial cancer in tamoxifen-treated breast cancer patients: findings from the National Surgical Adjuvant Breast and Bowel Project (NSABP) B-14. Journal of the National Cancer Institute 86 527-537.

Fisher B, Dignam J, Bryant J, DeCillis A, Wickerham DL, Wolmark N, Costantino J, Redmond C, Fisher ER, Bowman DM et al. 1996 Five versus more than five years of tamoxifen therapy for breast cancer patients with negative lymph nodes and estrogen receptor-positive tumors. Journal of the National Cancer Institute $\mathbf{8 8}$ 1529-1542.

Franco S, Perez A, Tan-Chiu E, Frankel C \& Vogel C 2004 Response to fulvestrant in postmenopausal women heavily pretreated with prior hormonal therapy: a singlecenter experience. Breast Cancer Research and Treatment 88 103-108.

Frasor J, Stossi F, Danes JM, Komm B, Lyttle R \& Katzenellenbogen BS 2004 Selective estrogen receptor modulators: discrimination of agonistic versus antagonistic activities by gene expression profiling in breast cancer cells. Cancer Research 64 1522-1533.

Gallagher A, Chambers TJ \& Tobias JH 1993 The estrogen antagonist ICI 182,780 reduces cancellous bone volume in female rats. Endocrinology 133 2787-2791.

Gauthier S, Caron B, Cloutier J, Dory YL, Favre A, Larouche D, Mailhot J, Ouellet C, Schwerdtfeger A, Leblanc G et al. 1997 (S)-(+)-4-[7-(2,2-dimethyl-1-oxopropoxy)-4methyl-2-[4-[2-(1-piperidinyl)- ethoxy]phenyl]-2H-1benzopyran-3-yl]-phenyl 2,2-dimethylpropanoate (EM-800): a highly potent, specific, and orally active nonsteroidal antiestrogen. Journal of Medicinal Chemistry 40 2117-2122.

Gershanovich M, Garin A, Baltina D, Kurvet A, Kangas L \& Ellmen J 1997 A phase III comparison of two toremifene doses to tamoxifen in postmenopausal women with advanced breast cancer. Eastern European Study Group. Breast Cancer Research and Treatment 45 251-262.

Goss PE, Ingle JN, Martino S, Robert NJ, Muss HB, Piccart MJ, Castiglione M, Tu D, Shepherd LE, Pritchard KI et al. 2003 A randomized trial of letrozole in postmenopausal women after five years of tamoxifen therapy for earlystage breast cancer. The New England Journal of Medicine 349 1793-1802.

Gradishar WJ, Glusman J, Lu Y, Vogel C, Cohen FJ \& Sledge GW Jr 2000 Effects of high dose raloxifene in selected patients with advanced breast carcinoma. Cancer 88 2047-2053.

Gustafsson JA \& Warner M 2000 Estrogen receptor $\beta$ in the breast: role in estrogen responsiveness and development of breast cancer. Journal of Steroid Biochemistry and Molecular Biology 74 245-248.

Haarstad H, Gundersen S, Wist E, Raabe N, Mella O \& Kvinnsland S 1992 Droloxifene - a new anti-estrogen. A phase II study in advanced breast cancer. Acta Oncologica 31 425-428.

Hanstein B, Djahansouzi S, Dall P, Beckmann MW \& Bender HG 2004 Insights into the molecular biology of the estrogen receptor define novel therapeutic targets for breast cancer. European Journal of Endocrinology 150 243-255.

Hayes DF, Van Zyl JA, Hacking A, Goedhals L, Bezwoda WR, Mailliard JA, Jones SE, Vogel CL, Berris RF, Shemano I et al. 1995 Randomized comparison of tamoxifen and two separate doses of toremifene in postmenopausal patients with metastatic breast cancer. Journal of Clinical Oncology 13 2556-2566. 
Hoffmann J, Bohlmann R, Heinrich N, Hofmeister H, Kroll J, Kunzer H, Lichtner RB, Nishino Y, Parczyk K, Sauer G et al. 2004 Characterization of new estrogen receptor destabilizing compounds: effects on estrogen-sensitive and tamoxifen-resistant breast cancer. Journal of the National Cancer Institute 96 210-218.

Horwitz KB \& McGuire WL 1978 Estrogen control of progesterone receptor and estrogen receptor in human breast cancer. Journal of Biological Chemistry 253 2223-2238.

Horwitz KB, Jackson TA, Bain DL, Richer JK, Takimoto GS \& Tung L 1996 Nuclear receptor coactivators and corepressors. Molecular Endocrinology 10 1167-1177.

Howell A \& Robertson J 1995 Response to a specific antioestrogen (ICI 182780) in tamoxifen-resistant breast cancer. Lancet 345 989-990.

Howell A, DeFriend DJ, Robertson JF, Blamey RW, Anderson L, Anderson E, Sutcliffe FA \& Walton P 1996 Pharmacokinetics, pharmacological and anti-tumour effects of the specific anti-oestrogen ICI 182780 in women with advanced breast cancer. British Journal of Cancer 74 300-308.

Howell A, Robertson JFR, Quaresma Albano J, Aschermannova A, Mauriac L, Kleeberg UR, Vergote I, Erikstein B, Webster A \& Morris C 2002 Fulvestrant, formerly ICI 182,780 , is as effective as anastrozole in postmenopausal women with advanced breast cancer progressing after prior endocrine treatment. Journal of Clinical Oncology 20 3396-3403.

Howell A, Robertson JFR, Abram P, Lichinitser MR, Elledge R, Bajetta E, Watanabe T, Morris C, Webster A, Dimery I et al. 2004 Comparison of fulvestrant $\mathrm{v}$ tamoxifen for the treatment of advanced breast cancer in postmenopausal women previously untreated with endocrine therapy: a multinational, double-blind, randomized trial. Journal of Clinical Oncology 22 1605-1613.

Howell A, Pippen J, Elledge RM, Mauriac L, Vergote I, Jones SE, Come SE, Osborne CK \& Robertson JF 2005 Fulvestrant versus anastrozole for the treatment of advanced breast carcinoma: a prospectively planned combined survival analysis of two multicenter trials. Cancer 104 236-239.

Hu XF, Veroni M, De Luise M, Wakeling A, Sutherland R, Watts CK \& Zalcberg JR 1993 Circumvention of tamoxifen resistance by the pure anti-estrogen ICI 182,780. International Journal of Cancer 55 873-876.

Hutcheson IR, Knowlden JM, Madden T-A, Barrow D, Gee JM, Wakeling AE \& Nicholson RI 2003 Oestrogen receptor-mediated modulation of the EGFR/MAPK pathway in tamoxifen-resistant MCF-7 cells. Breast Cancer Research and Treatment 81 81-93.

Ignar-Trowbridge DM, Teng CT, Ross KA, Parker MG, Korach KS \& McLachlan JA 1993 Peptide growth factors elicit estrogen receptor-dependent transcriptional activation of an estrogen-responsive element. Molecular Endocrinology 7 992-998.
Improta-Brears T, Whorton AR, Codazzi F, York JD, Meyer T \& McDonnell DP 1999 Estrogen-induced activation of mitogen-activated protein kinase requires mobilization of intracellular calcium. PNAS 96 4686-4691.

Ingle JN, Rowland KM, Suman VJ, Mirchandani D, Bernath AM, Camoriano JK \& Perez EA 2004 Evaluation of fulvestrant in women with advanced breast cancer and progression on prior aromatase inhibitor therapy: a phase II trial of the North Central Cancer Treatment Group. Breast Cancer Research and Treatment 88 (Suppl 1) S38, abstract 409.

Ingle JN, Suman VJ, Rowland KM, Mirchandani D, Bernath AM, Camoriano JK, Fishkin PA, Nikcevich DA \& Perez EA 2006 Fulvestrant in women with advanced breast cancer after progression on prior aromatase inhibitor therapy. North American Cancer Treatment Group Trial No. 32. Journal of Clinical Oncology 24 1052-1056.

Johnston SR, Gorbunova V, Lichinitser M, Manikas G, Koralewski P, Pluzanska A, Garin A, Harvey E \& International Idoxifene Study Group 2001 A multicentre double-blind randomised phase III trial of idoxifene versus tamoxifen as first-line endocrine therapy for metastatic breast cancer. Proceedings of the American Society of Clinical Oncology 20 29a, abstract 113 .

Katzenellenbogen JA, O'Malley BW \& Katzenellenbogen BS 1996 Tripartite steroid hormone receptor pharmacology: interaction with multiple effector sites as a basis for the cell- and promoter-specific action of these hormones. Molecular Endocrinology 10 119-131.

Kuiper G, Enmark E, Pelto-Huikko M, Nilsson MS \& Gustafsson JA 1996 Cloning of a novel estrogen receptor expressed in rat prostate and ovary. PNAS 93 5925-5930.

Kumar V \& Chambon P 1988 The estrogen receptor binds tightly to its responsive element as a ligand-induced homodimer. Cell 55 145-156.

Labrie F, Labrie C, Belanger A, Simard J, Gauthier S, LuuThe V, Merand Y, Giguere V, Candas B, Luo S et al. 1999 EM-652 (SCH 57068), a third generation SERM acting as pure antiestrogen in the mammary gland and endometrium. Journal of Steroid Biochemistry and Molecular Biology 69 51-84.

Labrie F, Champagne P, Labrie C, Roy J, Laverdiere J, Provencher L, Potvin M, Drolet Y, Pollak M, Panasci L et al. 2004 Activity and safety of the antiestrogen EM-800, the orally active precursor of acolbifene, in tamoxifen-resistant breast cancer. Journal of Clinical Oncology 22 864-871.

Lee ES, Schafer JM, Yao K, England G, O'Regan RM, De Los Reyes A \& Jordan VC 2000 Cross resistance of triphenylethylene-type antiestrogens but not ICI 182,780 in tamoxifen-stimulated breast tumors grown in athymic mice. Clinical Cancer Research 6 4893-4899.

Lindberg MK, Moverare S, Skrtic S, Gao H, DahlmanWright K, Gustafsson JA \& Ohlsson C 2003 Estrogen receptor (ER)-beta reduces ERalpha-regulated gene 
transcription, supporting a "Ying Yang" relationship between ERalpha and ERbeta in mice. Molecular Endocrinology 17 203-208.

Lykkesfeldt AE, Larsen SS \& Briand P 1995 Human breast cancer cell lines resistant to pure anti-estrogens are sensitive to tamoxifen treatment. International Journal of Cancer 61 529-534.

Marttunen MB, Hietanen P, Tiitinen A \& Ylikorkala O 1998 Comparison of effects of tamoxifen and toremifene on bone biochemistry and bone mineral density in postmenopausal breast cancer patients. Journal of Clinical Endocrinology and Metabolism 83 1158-1162.

Marttunen MB, Cacciatore B, Hietanen P, Pyrhonen S, Tiitinen A, Wahlstrom T \& Ylikorkala O 2001 Prospective study on gynaecological effects of two antioestrogens tamoxifen and toremifene in postmenopausal women. British Journal of Cancer 84 897-902.

Matthews J, Wihlén B, Tujague M, Wan J, Ström A \& Gustafsson JA 2006 ER $\beta$ modulates ER $\alpha$-mediated transcriptional activation by altering the recruitment of c-Fos and c-Jun to estrogen responsive promoters. Molecular Endocrinology 20 534-543.

Mauriac L, Pippen JE, Quaresma Albano J, Gertler SZ \& Osborne CK 2003 Fulvestrant (Faslodex) versus anastrozole for the second-line treatment of subgroups of postmenopausal women with visceral and nonvisceral metastases: combined results from two multicentre trials. European Journal of Cancer 39 1228-1233.

McClelland RA, Manning DL, Gee JM, Anderson E, Clarke R, Howell A, Dowsett M, Robertson JF, Blamey RW, Wakeling AE et al. 1996 Effects of short-term antiestrogen treatment of primary breast cancer on estrogen receptor mRNA and protein expression and on estrogenregulated genes. Breast Cancer Research and Treatment 41 31-41.

Milla-Santos A, Milla L, Rallo L \& Solano V 2001 Phase III randomized trial of toremifene vs tamoxifen in hormonodependent advanced breast cancer. Breast Cancer Research and Treatment 65 119-124.

Mouridsen H, Gershanovich M, Sun Y, Perez-Carrion R, Boni C, Monnier A, Apffelstaedt J, Smith R, Sleeboom HP, Jaenicke F et al. 2003 Phase III study of letrozole versus tamoxifen as first-line therapy of advanced breast cancer in postmenopausal women: analysis of survival and update of efficacy from the International Letrozole Breast Cancer Group. Journal of Clinical Oncology 21 2101-2109.

Munster PN, Buzdar A, Dhingra K, Enas N, Ni L, Major M, Melemed A, Seidman A, Booser D, Theriault R et al. 2001 Phase I study of a third-generation selective estrogen receptor modulator, LY353381.HCL, in metastatic breast cancer. Journal of Clinical Oncology 19 2002-2009.

Nabholtz JM, Buzdar A, Pollak M, Harwin W, Burton G, Mangalik A, Steinberg M, Webster A \& von Euler M 2000 Anastrozole is superior to tamoxifen as first-line therapy for advanced breast cancer in postmenopausal women: results of a North American multicenter randomized trial. Arimidex Study Group. Journal of Clinical Oncology 18 3758-3767.

Newton CJ, Buric R, Trapp T, Brockmeier S, Pagotto U \& Stalla GK 1994 The unliganded estrogen receptor (ER) transduces growth factor signals. Journal of Steroid Biochemistry and Molecular Biology 48 481-486.

Nicholson RI, Gee JM, Manning DL, Wakeling AE, Montano MM \& Katzenellenbogen BS 1995 Responses to pure antiestrogens (ICI 164,384, ICI 182,780) in estrogensensitive and -resistant experimental and clinical breast cancer. Annals of the New York Academy of Sciences 761 $148-163$.

Nicholson RI \& Johnston SR 2005 Endocrine therapy current benefits and limitations. Breast Cancer Research and Treatment 93 (Suppl 1) S3-S10.

Norris JD, Fan D, Kerner SA \& McDonnell DP 1997 Identification of a third autonomous activation domain within the human estrogen receptor. Molecular Endocrinology 11 747-754.

Osborne CK, Jarman M, McCague R, Coronado EB, Hilsenbeck SG \& Wakeling AE 1994 The importance of tamoxifen metabolism in tamoxifen-stimulated breast tumor growth. Cancer Chemotherapy and Pharmacology 34 89-95.

Osborne CK, Coronado-Heinsohn EB, Hilsenbeck SG, McCue BL, Wakeling AE, McClelland RA, Manning DL \& Nicholson RI 1995 Comparison of the effects of a pure steroidal antiestrogen with those of tamoxifen in a model of human breast cancer. Journal of the National Cancer Institute 87 746-750.

Osborne CK, Pippen J, Jones SE, Parker LM, Ellis M, Come S, Gertler SZ, May JT, Burton G, Dimery I et al. 2002 Double-blind, randomized trial comparing the efficacy and tolerability of fulvestrant versus anastrozole in postmenopausal women with advanced breast cancer progressing on prior endocrine therapy: results of a North American trial. Journal of Clinical Oncology 20 3386-3395.

Paech K, Webb P, Kuiper GG, Nilsson S, Gustafsson J, Kushner PJ \& Scanlan TS 1997 Differential ligand activation of estrogen receptors ERalpha and ERbeta at AP1 sites. Science 277 1508-1510.

Paige LA, Christensen DJ, Gron H, Norris JD, Gottlin EB, Padilla KM, Chang CY, Ballas LM, Hamilton PT, McDonnell DP et al. 1999 Estrogen receptor (ER) modulators each induce distinct conformational changes in ER alpha and ER beta. PNAS 96 3999-4004.

Paridaens R, Dirix L, Lohrisch C, Beex L, Nooij M, Cameron D, Biganzoli L, Cufer T, Duchateau L, Hamilton A et al. 2003 Mature results of a randomized phase II multicenter study of exemestane versus tamoxifen as first-line hormone therapy for postmenopausal women with metastatic breast cancer. Annals of Oncology 14 1391-1398.

Perey L, Paridaens R, Nolé F, Bonnefoi H, Aebi S, Goldhirsch A, Dietrich D \& Thürlimann B for the Swiss 
Group for Clinical Cancer Research (SAKK) 2004 Fulvestrant (Faslodex ${ }^{\mathrm{TM}}$ ) as hormonal treatment in postmenopausal patients with advanced breast cancer (ABC) progressing after treatment with tamoxifen and aromatase inhibitors: update of a phase II SAKK trial. Breast Cancer Research and Treatment 88 (Suppl 1) S236, abstract 6048.

Petruzelka L, Zimovjanova M, Konopasek B, Mares P \& Dlouha Z 2004 Fulvestrant in postmenopausal women with metastatic breast cancer progressing on prior endocrine therapy - updated results from an expanded access programme. Annals of Oncology 15 (Suppl 3) iii36, abstract $136 \mathrm{P}$.

Pyrhonen S, Valavaara R, Vuorinen J \& Hajba A 1994 High dose toremifene in advanced breast cancer resistant to or relapsed during tamoxifen treatment. Breast Cancer Research and Treatment 29 223-228.

Pyrhonen S, Valavaara R, Modig H, Pawlicki M, Pienkowski T, Gundersen S, Bauer J, Westman G, Lundgren S, Blanco G et al. 1997 Comparison of toremifene and tamoxifen in post-menopausal patients with advanced breast cancer: a randomized doubleblind, the 'nordic' phase III study. British Journal of Cancer 76 270-277.

Pyrhonen S, Ellmen J, Vuorinen J, Gershanovich M, Tominaga T, Kaufmann M \& Hayes DF 1999 Metaanalysis of trials comparing toremifene with tamoxifen and factors predicting outcome of antiestrogen therapy in postmenopausal women with breast cancer. Breast Cancer Research and Treatment 56 133-143.

Qi X, Stanley B, Pramanik R, Schultz RM, Han J \& Chen G 2004 Estrogen receptor inhibits c-Jun-dependent stressinduced cell death by binding and modifying c-Jun activity in human breast cancer cells. Journal of Biological Chemistry 279 6769-6777.

Reese JC \& Katzenellenbogen BS 1991 Differential DNAbinding abilities of estrogen receptor occupied with two classes of antiestrogens: studies using human estrogen receptor overexpressed in mammalian cells. Nucleic Acids Research 19 6595-6602.

Robertson JF, Nicholson RI, Bundred NJ, Anderson E, Rayter Z, Dowsett M, Fox JN, Gee JM, Webster A, Wakeling AE et al. 2001 Comparison of the short-term biological effects of 7alpha-[9-(4,4,5,5,5-pentafluoropentylsulfinyl)-nonyl]estra-1,3,5, (10)-triene-3,17betadiol (Faslodex) versus tamoxifen in postmenopausal women with primary breast cancer. Cancer Research 61 6739-6746.

Robertson JF, Osborne CK, Howell A, Jones SE, Mauriac L, Ellis M, Kleeberg UR, Come SE, Vergote I, Gertler S et al. 2003 Fulvestrant versus anastrozole for the treatment of advanced breast carcinoma in postmenopausal women - a prospective combined analysis of two multicenter trials. Cancer 98 229-238.

Robertson JFR, Gutteridge E, Cheung KL, Pinder S \& Wakeling A 2004 Oestrogen receptor expression in human breast cancer during long-term fulvestrant treatment. Proceedings of the American Society of Clinical Oncology 11, abstract 536.

Robertson JF, Howell A, Gorbunova VA, Watanabe T, Pienkowski T \& Lichinitser MR 2005 Sensitivity to further endocrine therapy is retained following progression on first-line fulvestrant. Breast Cancer Research and Treatment 92 169-174.

Roy J, Couillard S, Gutman M \& Labrie F 2003 A novel pure SERM achieves complete regression of the majority of human breast cancer tumors in nude mice. Breast Cancer Research and Treatment 81 223-229.

Shiau AK, Barstad D, Loria PM, Cheng L, Kushner PJ, Agard DA \& Greene GL 1998 The structural basis of estrogen receptor/coactivator recognition and the antagonism of this interaction by tamoxifen. Cell 95 927-937.

Shupnik MA 2004 Crosstalk between steroid receptors and the c-src-receptor tyrosine kinase pathways: implications for cell proliferation. Oncogene 23 7979-7989.

Sibonga JD, Dobnig H, Harden RM \& Turner RT 1998 Effect of the high-affinity estrogen receptor ligand ICI 182,780 on the rat tibia. Endocrinology 139 3736-3742.

Smith CL, Conneely OM \& O’Malley BW 1993 Modulation of the ligand-independent activation of the human estrogen receptor by hormone and antihormone. PNAS 90 6120-6124.

Steger GG, Bartsch R, Wenzel C, Pluschnig U, Hussain D, Sevelda U, Locker GJ, Gnant MF, Jakesz R \& Zielinski CC 2005 ('Faslodex') in pre-treated patients with advanced breast cancer. European Journal of Cancer 41 2655-2661.

Stenbygaard LE, Herrstedt J, Thomsen JF, Svendsen KR, Engelholm SA \& Dombernowsky P 1993 Toremifene and tamoxifen in advanced breast cancer - a double-blind cross-over trial. Breast Cancer Research and Treatment 25 57-63.

Taras TL, Wurz GT \& DeGregorio MW 2001 In vitro and in vivo biologic effects of Ospemifene (FC-1271a) in breast cancer. Journal of Steroid Biochemistry and Molecular Biology 77 271-279.

Tsai MJ \& O’Malley BW 1994 Molecular mechanisms of action of steroid/thyroid receptor superfamily members. Annual Review of Biochemistry 63 451-486.

Tzukerman MT, Esty A, Santiso-Mere D, Danielian P, Parker MG, Stein RB, Pike JW \& McDonnell DP 1994 Human estrogen receptor transactivational capacity is determined by both cellular and promoter context and mediated by two functionally distinct intramolecular regions. Molecular Endocrinology 8 21-30.

van de Velde CJ, Nique F, Bouchoux F, Bremaud J, Hameau MC, Lucas D, Moratille C, Viet S, Philibert D \& Teutsch G 1994 RU 58,668, a new pure antiestrogen inducing a regression of human mammary carcinoma implanted in nude mice. Journal of Steroid Biochemistry and Molecular Biology 48 187-196.

Vergote I, Robertson JFR, Kleeberg U, Burton G, Osborne CK \& Mauriac L 2003 Postmenopausal women who 
progress on fulvestrant ('Faslodex') remain sensitive to further endocrine therapy. Breast Cancer Research and Treatment 79 207-211.

Wakeling AE 1995 Use of pure antioestrogens to elucidate the mode of action of oestrogens. Biochemical Pharmacology 49 1545-1549.

Wakeling AE 2000 Similarities and distinctions in the mode of action of different classes of antioestrogens. EndocrineRelated Cancer 7 17-28.

Wakeling AE \& Bowler J 1987 Steroidal pure antioestrogens. Journal of Endocrinology 112 R7-R10.

Wakeling AE, Dukes M \& Bowler J 1991 A potent specific pure antiestrogen with clinical potential. Cancer Research 51 3867-3873.

Webb P, Nguyen P \& Kushner PJ 2003 Differential SERM effects on corepressor binding dictate ER $\alpha$ activity in vivo. Journal of Biological Chemistry 278 6912-6920.
Weigel NL \& Zhang Y 1998 Ligand-independent activation of steroid hormone receptors. Journal of Molecular Medicine 76 469-479.

White R \& Parker MG 1998 Molecular mechanisms of steroid hormone action. Endocrine-Related Cancer $\mathbf{5}$ $1-14$.

Wijayaratne AL, Nagel SC, Paige LA, Christensen DJ, Norris JD, Fowlkes DM \& McDonnell DP 1999 Comparative analyses of mechanistic differences among antioestrogens. Endocrinology 140 5828-5840.

Yamamoto Y, Shibata J, Yonekura K, Sato K, Hashimoto A, Aoyagi Y, Wierzba K, Yano S, Asao T, Buzdar AU \& Terada T 2005 TAS-108, a novel oral steroidal antiestrogenic agent, is a pure antagonist on estrogen receptor alpha and a partial agonist on estrogen receptor beta with low uterotrophic effect. Clinical Cancer Research 11 315-322. 